\title{
HIV and/or AIDS, migrant labour and the experience of God: A practical theological postfoundationalist approach
}

\author{
Authors: \\ Keith August ${ }^{1}$ \\ Julian C. Müller ${ }^{1}$ \\ Affiliations: \\ ${ }^{1}$ Department of Practical \\ Theology, University of \\ Pretoria, South Africa \\ Note: \\ Keith August has done \\ the primary research as \\ part of his PhD degree in \\ Pastoral Family Therapy \\ under the supervision of \\ Prof. Julian C. Müller of \\ the Department Practical \\ Theology, University of \\ Pretoria. \\ Correspondence to: \\ Julian Müller \\ email: \\ julian.muller@up.ac.za \\ Postal address: \\ PO Box 626, Wapadrand, \\ Pretoria 0002, South Africa \\ Dates: \\ Received: 03 Dec. 2009 \\ Accepted: 10 July 2010 \\ Published: 28 Mar. 2011 \\ How to cite this article \\ August, A. \& Müller, J.C \\ 2011, 'HIV and/or AIDS \\ migrant labour and the \\ experience of God: A \\ practical theological \\ postfoundationalist \\ approach', HTS Teologiese \\ Studies/Theological Studies \\ 67(3), Art. \#774, 6 pages. \\ DOI:10.4102/hts.v67i3.774
}

(C) 2011. The Authors. Licensee: OpenJournals Publishing. This work is licensed under the Creative Commons Attribution License.
Migrant workers in the Deciduous Fruit Industry are part of the marginalised communities in South Africa who have been severely affected by HIV and/or AIDS. A postfoundationalist approach and the Seven Movements proposed by Müller were traced to present the research undertaken amongst migrant workers with HIV or AIDS. The practical theological investigation was developed from the praxis of HIV and AIDS and the question that it aimed to answer was: 'What is the experience of God in the lives of persons affected by or infected with HIV / AIDS?' Whilst it is understood that Christian belief has its own, exclusive integrity, if it is to be valid, it should be able to incorporate the different dimensions of our modern practice to give it the maximum level of meaning and significance.

\section{Introduction}

Writing about the experiences of God in the lives of migrant workers with HIV or AIDS happened gradually as interactions with people infected with HIV drew me into their world. This research was an attempt to obtain a better understanding of the lived experiences of migrant workers infected with or affected by HIV and/or AIDS. I tried to explore avenues of coping with the crisis that HIV and AIDS presents on the one hand and religious belief on the other.

This research enabled me to listen to and discover how some migrant workers experienced God when affected by or infected with HIV and/or AIDS. They became co-researchers and my research was limited to what they allowed me to see about their experiences of God. Denzin and Lincoln (2008) remind us that:

Qualitative research is a situated activity that locates the observer in the world. It consists of a set of interpretive material practices which make the world visible. These practices transform the world they turn the world into a series of representations, including field notes, interviews, conversations, photographs, recordings, and memos to the self.

(Denzin \& Lincoln 2008:5)

My limited exposure to this world helped to give birth to this research.

During the course of my investigation, I observed my co-researchers 'in action' at home, the workplace and amongst peers. They were individuals that I encountered initially in the workplace and later in their homes. Some of them were infected with HIV, whilst others had still lower CD4 counts and could be regarded as having AIDS. Other members of this group were healthy people, but as a result of their relationship with the infected individual they were also affected by HIV and/or AIDS. A further group of co-researchers were members of the scientific community, who read the stories of my co-researchers and provided feedback, which formed part of this research.

This article presented a glance into this world. However, it was not my intention to merely describe it. Instead, I wanted to listen and help others to understand the stories of my co-researchers in real life situations. Denzin and Lincoln (2008) posed three questions to help guide the research process, for example:

- ontology (What kind of being is the human being? What is the nature of reality?)

- epistemology (What is the relationship between the enquirer and the known?)

- methodology (How do we know the world, or gain knowledge of it?).

(Denzin \& Lincoln 2008:33)

Hart (1998:86) has been supportive regarding the design of research questions. He also seeks to clarify the ontological, epistemological and methodological issues and the personal values and ethics of the researcher.

\section{Ethical considerations}

My initial reaction was frantic, in the sense that people were not co-operative and no one seemed to be concerned with passing me any information on people with HIV. I had to obtain permission 
from the individuals who were prepared to allow my intrusion in their lives. I invited a number of co-researchers, as described previously, to engage with me in this research project. The project was prompted by my aspiration to understand and at a later stage attempt to illuminate how some people affected by and infected with HIV and/or AIDS make sense of their experience.

My co-researchers were presented with their own stories for approval before I offered it in this form. Accountability towards them remains a priority. It is important to report that not all of the participants were HIV-positive, but that some of them were affected by HIV and/or AIDS in some other way, through losing a partner or children for example. During my research, I focused solely on adults, simply because we were in a work environment. I have used pseudonyms to protect the identities of my co-researchers, which helped to reduce their vulnerability.

Information was gathered through the observation of participants and I looked at the behaviour of the individuals who agreed to be part of my research. Some were isolating themselves from their peers for fear of ostracism. I have seen co-researchers who have become insecure as a result of the effects of the illness on their performance in the workplace. I sensed that some of my co-researchers were looking for a better understanding of God through the type of questions they asked and the interest they showed when asked about God. Others withdrew when we spoke about God. I made use of open-ended interviews where their conclusions became important to both of us as we tried to make sense of a constant evolving situation.

These stories, or knowledge, were transferred from coresearcher to researcher. I presented my observations to my co-researchers for review, to ensure that it was a true reflection of their views. After confirming or changing some of the information, I presented their stories to members of the scientific community, who had volunteered to give interpretations from their perspective. Although I wrote the story, I still regard my co-researchers as the co-authors of their stories. It is important to note that my research is titled: 'HIV and/or AIDS, migrant labour and the experience of God'. This presupposes that my research focused only on migrant labourers and their families and that it excluded other people in Grabouw who are infected with or affected by HIV and/or AIDS was not included.

My co-researchers were limited to those participants who were willing to engage with me in this research. This article, through the voice of the researcher or author, also tells a story of the people involved, the 'participants' in my 'study'. There were many cherished moments in the presence of my co-researchers. I have gathered information through various methods, including participant observation and open-ended interviewing. During the course of my work as Human Resources (HR) Practitioner, people opened up to me and shared vital information with me.

\section{Socio cultural background of this research}

Some of these stories do not point to a happy conclusion. Presently, many marginalised co-researchers are bruised and struggling with the knowledge that they have been affected by or infected with HIV and/or AIDS. Suddenly, their life expectancy has been altered or the quality of life that they knew changed as they struggle with a disease. People who are otherwise healthy are sitting in doctor's surgeries or find themselves in a counselling situation or even unemployment. The role of partners and family members have been altered and infected or affected individuals become more dependent upon each other, members of the helping community and the church.

Infected or affected people are often confronted with bureaucratic government institutions like the Department of Social Services, Department of Labour and the Department of Health. The waiting period at these overloaded institutions is soon forgotten when assistance is provided. Out of work benefits become a reality for the previously employed, but now disabled individual. Some individuals will receive a grant from social services, others will find a place in our hospitals. But for some people it may be too late. Murphy and Perry (1989) sum the mood up as follows:

Family members are afraid of society censure: they are embarrassed or ashamed or feel guilty or angry, and they shed their tears, swallow their sobs, and try to be 'normal' although their hearts are heavy and their spirits are burdened. By caring openly and compassionately for people infected /affected with HIV, the caregiver reduces the community's fear of the infection, and this alleviates stigma and discrimination. Open participatory, inclusive and compassionate care particularly at home can influence attitudes positively towards co-researcher living with HIV and AIDS.

(Murphy \& Perry 1989:291)

One of the early steps of the research was to identify the different types of stories, for example stories of hope or stories of loss and grief in the lives of my co-researchers. In this small village, located in the Overberg, some family members of coresearchers might experience pain, shame, guilt, rejection and even fear, poverty, divorce or death within the family. The array of possibilities is endless. In an attempt to understand it better, there was co-operation between researcher and coresearcher as some of the significant occurrences in the coresearcher's life was discussed. These served as important points of reference in the thematic organisation of the narrative and are expressions of how families experienced the world they live in and interpret it. It is through interpretive acts that such people find meaning in their experiences of the world. There is many ways of constructing the world, in a world of rich potentials. These interpretive acts make their experience of life sensible to themselves and to others. In all considerations of people's expressions of life, meaning and experience are inseparable.

Through these interpretive acts, a sense of hope was discovered as the situation presented alternatives for migrant workers by allowing individuals and families who 
are affected by HIV and/or AIDS a place for the expression of their experiences. The unique pattern of our individual story separates us, whilst the sharing of our experiences reveals our similarities and draws us together. It was through the listening of these stories that I could influence the establishment of employee assistance and wellness programs in this area. The migrant workers demonstrated hospitality when I entered their homes and hospital wards. In its partnership with the grim reaper, HIV and AIDS has taken its toll, given that small children are left as orphans, spouses become single and mothers and fathers bury their children although they were unprepared for death. These coresearchers allowed me to see their scars and for that I am humbled.

I was transposed to the inner chambers of my co-researcher's lives and relationships, where betrayal was exposed and confronted as HIV and AIDS shredded relationships. I saw how a fleeting moment of infidelity turns into a horror of horrors, as a wife realised the impact of the disease upon her situation. Entering the homes of my co-researchers gave me an acute awareness of the privilege afforded me to enter this world, where HIV or AIDS run rampant. Hospitals, clinics, doctor's surgeries and sick notes from traditional healers became part of the new reality of my position as HR Practitioner.

My work and home life became intertwined with HIV and AIDS and with it came the opportunity to make sense of God in the lives of my co-searchers. I considered interrelations with God, including their secular worldview. Our battle with HIV continued and co-researchers were beginning to make sense of their situation. My initial exploration of migrant workers and their experience of God were purely for the sake of learning. I gravitated towards Employee Assistance as well as Corporate Social Responsibility in the work place. It is in this process that I recovered experiences in my own life whilst interacting with my co-researchers.

\section{Positioning this research A postfoundationalist approach}

During the writing of this article, I consciously considered the reader, who has been drawn into this interdisciplinary discussion. What how would the reader experience this world? The discussion over the justification of belief is intimately related to the question about how individual and shared factors shape the formation of beliefs. It is possible for the researcher to gravitate towards foundationalism or nonfoundationalism. Both approaches have inherent weaknesses. Braaten and Clayton (1988:21) repeat Annenberg's observation that ' $20^{\text {th- }}$-century existentialist theologies have tended to compartmentalise reason and faith into separate spheres, thereby shielding faith from the potential critical findings of reason (i.e., scientific discovery)'. This appeal to some item of knowledge that is self-evident or unquestionable is implied as being inflexible or infallible. Van Huyssteen (1977) suggests that: these foundations for our knowledge are accepted as givens and therefore treated as a privileged class of aristocratic beliefs that serves as ultimate terminating points in the argumentative chain of justification for our views.

(Van Huyssteen 1977:3)

He perceives its artificial criterion of consensus as the main error of foundationalism.

Müller (2009:4) highlights the pitfalls of the nonfoundational position, which claims that no theoretical agreement can be a conceivable basis for knowledge, because of the sceptism regarding any effort to create mutual understanding.

What is tested in this approach is our own rationality. What is tested here is our not so much God but our own various set of beliefs about God, about the nature of God, about God's actions in the world, and about what we see as God's will for us and for our world.

(Van Huyssteen 1977:3)

I have looked at both of these approaches and prefer a postfoundationalist approach, appealing to praxis instead of a claim for universal validity or multiversal rationality. I wanted to argue for some sort of postfoundationalist epistemic structure that would allow for certainty. This socially constructed interpretation is geared towards a postfoundationalist approach, continually influenced by social and linguistic conditions. Listening to many voices enabled me to pay attention to the stories of people in real life situations. Instead of generalising, I am able to reflect on embodied people rather than abstract beliefs. Postfoundationalism acknowledges contextually the crucial epistemic role of interpreted experience and paves the way for interdisciplinary conversation.

Thomáš Hančil (1999:3) also argues for transversal rationality. He suggests that a postfoundational position would enable him to fully acknowledge the role of context, the crucial epistemic role of interpreted experience and the way that tradition shapes the epistemic and non-epistemic values that inform our reflection of God. 'These, at the same time point creatively beyond the confines of a local community, group or culture, towards a form of cross cultural and interdisciplinary conversation'. Social constructionism offered an opportunity for persons affected by or infected with HIV and/or AIDS to become part of a collaborative enquiry because it allows for increased or improved relationship and language.

\section{The seven movement procedure}

The narrative approach to qualitative research was used and conducted according to the seven movements developed by Muller (2005:72-88) on the basis of postfoundationalist practical theology. A postfoundationalist approach according to the following design may improve the investigative ability of this research and has helped to conceptualise further aspects of my co-researchers experiences. In this design, a specific context, where some migrant workers in the Overberg were affected by or infected with HIV and/or AIDS, was examined and some of our experiences communicated. A social constructionist approach helped to reflect on the experience 
and presence of God, whilst practical theology helped with the critical theological reflection on the practice of the church with the intention of ensuring enabling participation in Gods redemptive practices in and for the world. Interpretations of these experiences were made in collaboration with my co-researchers and further described and developed in collaboration with members of the scientific community. I believe that, although this approach concerned itself with a better comprehension of migrant workers' understanding of God, it certainly evolved beyond the local community.

I anticipated that postfoundationalist practical theology might provide the structure and words for interpreting some of the events in my co-researcher's lives. Very helpful in this regard was Van Huyssteen, who begs the question whether Christian theology can ever really claim to join this postmodern conversation without retreating to an impenetrable world of private, narrow-minded knowledge claims (Van Huyssteen 1977:2). In this postfoundational theology, we have recognised contextually the epistemically influential roles of presumed experience and how it points beyond the confines of the local community. This form of theological reflection might offer a critique of foundational rationality and shape the way in which theology is located within interdisciplinary reflection.

\section{In reflecting on this approach, Müller (2005) suggests:}

For practical theology to reflect in a meaningful way on the experiences and presence of God, it need to be locally, contextual and socially constructed, directed by tradition exploring interdisciplinary meaning and it need to point beyond the local.

(Müller 2005:78)

The postfoundationalist approach forced me to listen to the stories of people in real life situations, the stories of people who were affected by or infected with HIV or AIDS. Research-wise, their stories did not always give the desired results; the outcomes were unique and every story different.

The possibility of locating this research within an interdisciplinary context enabled the reconstruction of the conversations within a participatory action research design. As human beings, we interpret and:

relate to our world epistemically only through the mediation of interpreted experience, the observer or the knower is always in relationship to what is known, and thus always limited in perspective, in focus, and in experiential scope.

(Van Huyssteen 1997:20)

The re-authorising of conversations explores the specifics of how the person has been effective at reducing, changing or eliminating the problem.

In a postfoundational model of rationality, hermeneutics and epistemology are closely linked. The meanings that we give to these events are not neutral in their effects on our lives, but will constitute and shape our futures. This meaning forms the plot of the story. People affected by HIV and/or AID Sconstantly give meanings to their experiences, for instance, stories about themselves, their abilities, struggles, competencies, actions and so forth.
The methods we employ to reduce, change or eliminate our problems are carefully articulated during the interview process. Van Huyssteen (1997:23) suggests that those who seek to identify their experience in religious terms are seeking the best available explanation for what is happening to them.

Life is multistoried and a postfoundational model of rationality should include an interpretation of religious practice that rise above the pitfalls that demands a reductionist choice between issues. We have various perspectives of reality, for example the social, ethical, moral and aesthetic dimensions. There are many stories that occur at the same time and different stories that can be told about the same events. In one of the stories told, there was an example where a mother's family, feeling that the partner did not fulfil his customary duties and that their sister's bridal dowry was dishonoured, laid claim on their son. The partner, on the other hand, felt that the family were just interested in the financial rewards when adopting his son. Here is the evidence that no single story can be free of ambiguity or contradiction or encapsulate and handle all the contingencies of life because of the transactional and relational nature of all experience.

There are many different sorts of stories by which we live our lives and relationships, including stories about the past, present and future. Stories can also belong to individuals and/or communities. There can be family stories and relationship stories. Individuals might have stories about themselves being successful and competent. Families might have stories about themselves being 'caring', 'noisy', 'risky', 'dysfunctional' or 'close'. A community might have a story about itself as 'isolated', 'politically active' or 'financially strong'. All of these stories could be occurring at the same time and events, as they occur, will be interpreted according to the meaning (plot) that is dominant at that time. In this way, the act of living requires us to engage in the mediation between the dominant and the alternative stories of our lives. We are always negotiating and interpreting our experiences.

In an attempt to help validate the stories of my co-researchers, I invited members of the scientific community to reflect on this research. I exposed them to my co-researchers' stories, which they then read. These participants were impartial and objective and included a clinic sister, a social worker, an employee on a farm and a wellness practitioner. Barbie and Mouton (2001) state that:

a scientific belief is held to be rational when communities of rational and expert agents (such as the scientific community) have submitted such believe to joint scrutiny and accepted it as the most plausible claim.

(Barbie \& Mouton 2001:11)

As explained previously, the seven movements proposed by Muller (2009) were used in this research. In an attempt to explore this transversal rationality further, I made use of his four questions to gain a response from members of the scientific community:

- When reading the stories of my co-researchers, what is your response? 
- What do you think is your discipline's unique perspective on this story?

- Why do you think your perspective will be understood and appreciated by people from other disciplines?

- What would be a major concern if your discipline might not be taken seriously?

The clinic sister responded that as someone who works with many sick people, she uses medical and scientific language and wonders if she should adjust the antiretroviral (ARV) prescriptions of people infected with HIV and/or AIDS. Her concern is for people to become aware of their HIV status and manage the disease to prevent further infections. The Employee Assistance Practitioner was concerned about awareness, as well as the emotional and practical aspects of people living with HIV or AIDS; the impact of HIV and AIDS at home or in the hostel on the person that is infected, the children and other inhabitants. She is also worried about the secrecy surrounding HIV and AIDS. The social worker had a more pragmatic approach and wanted a team of officials to arrange disability grants. As a HR Practitioner and HIV coordinator, my concerns would be work related, in terms of an employee's ability to earn a living. Accommodation and the coping ability of a family would be a major concern. Should this approach not be taken seriously in the work place, invariably more employees will be lost and more employees will lose their lives because of a lack of care. Unemployed people are also more vulnerable.

Transversal rationality takes into account that there are many different 'rationalities' at work in society. Examining the experiences of my co-researchers from different perspective provides a richness that is impossible to achieve from a single perspective. It also establishes an appreciation of the complexities involved in the life of people affected by or infected with HIV and/or AIDS. Those who work with people affected by HIV and/or AIDS must begin to see them as people with a wide array of needs. They must also recognise individuals and their thoughts as the expert of their own situation.

Transversal rationality acknowledges these different rationalities that are at play in a pluralistic environment. Every person has his or her own perspective and their words give us windows to understand their situations. As a method, it proposes that we look for intersections to enter into dialogue at those concrete, situated moments. We must do so, however, with 'epistemic humility'; we need to be open to theoretical correction. I do not tell the clinic sister that she is wrong in bringing medical, scientific and pharmacological reasoning to bear on the migrant workers' problems. Neither would I dissuade the social worker's team of officials to arrange disability grants. As HR Practitioner and HIV coordinator, I bring a different perspective to the table in terms of job security, labour relations and corporate social responsibility. I also bring a distinctively Christian rationality to bear on the situation of these workers' problems. I can respectfully and sensitively articulate that rationality and I will be shedding light ('truth') on the situation.
The validity of the social construction of experience can be accepted. I hope that the transformation that this research brought through personal religious experience will lead to a better understanding and a means to better comprehend the lived experiences of people affected by HIV and/or AIDS. As mentioned previously, Van Huyssteen (1977:2) begs the question whether Christian theology can ever really claim to join this post-modern conversation without retreating to an impenetrable world of private, narrow-minded knowledge claims. By locating this research within an interdisciplinary context, the conversations are re-authorised within participatory action research. People affected by HIV and/or AIDS constantly give meanings to their experiences. The methods we employ to reduce, change or eliminate the problems are carefully articulated. The eminent religious understanding in this sense would be the individual's decision about an incident and the philosophy that amount to a religious experience.

There are many stories, which occur at the same time, about similar events. Stories can also belong to individuals and/or communities. Most of the stories in this research were stories of suffering. Sadly, most of these continue; every day the plot thickens, the story line alters and lives are affected. We have seen in the story of one of my co-researchers how two individuals developed different perspectives on the same event after his partner's family laid claim to his son. I was able to hear both his story and the story told by his sister-in-law. No single story can be free of ambiguity or contradiction or encapsulate and handle all the contingencies of life, because of the transactional and relational nature of all experiences.

Van Huyssteen (1998:32) is helpful in encouraging the researcher to enter the pluralist interdisciplinary conversation. I had time to pull back and receive the knowledge that emerged from my co-researchers, instead of rushing in with clever interventions or 'truth formulations'. My coresearchers were respected as the experts of their own stories as we placed theology in the heart of the interdisciplinary conversations. The presentation of the individual stories of my co-researchers goes beyond the scope of this article.

By caring openly and compassionately for people infected with HIV, the caregiver reduces the community's fear of HIV infection and alleviates stigma and discrimination. Open, participatory, inclusive and compassionate care, particularly at home, can influence a personal, family and community change of attitude positively towards co-researcher living with HIV or AIDS. The method is about co-operation between researcher and co-researchers. It is through interpretive acts that people affected by HIV find meaning in their experiences of the world. In all considerations of people's expressions of life, meaning and experience are inseparable. A qualitative narrative analysis is open to the construction of alternative stories. This will influence social relationships, directing the co-researcher's focus toward a better understanding of HIV and AIDS. These expressions are constitutive of life and have real effects in terms of the shaping and transforming life. 
AIDS is an illness that has a profound impact on the family members who live with and love the infected person. Some people who are HIV-positive withdraw from others and isolate themselves. AIDS as an illness often afflicts numerous people in a family system and it may happen that a number of people in the same family have HIV. When family members are perplexed and confused about why their relative is behaving differently, they may become angry at each other and family problems may be exacerbated. Persons affected by or infected with HIV and/or AIDS need someone to hear and validate their feelings. This action involves the sharing of experiences, as it informs traditions of interpretation.

In considering the church's role, it was important to me to reflect on the experiences and presence of God. It is my perception that the church has a struggle to assist people with HIV. In my limited exposure to churches in the Overberg, I have seen restricted interaction on the side of the church with regards to people affected by HIV and AIDS, which could be expanded despite limited resources. I believe that an altered approach is needed to make a difference in the lives of people who are affected by HIV and/or AIDS. In using the narrative approach, I could look at some factors that could contribute to a new story in the lives of these people. This quest led to a journey of observation as I observed congregations in the different communities. I believe that members of the more affluent community could assist members of the fringe community in a more meaningful way, without being patronising. However, I do regard offering hope to members of a less privileged community as a task that is relevant for the church today.

\section{Conclusion}

HIV and/or AIDS, migrant labour and the experience of God offered me an opportunity to gain a better comprehension of migrant workers and their understanding of God. My limited grasp of HIV and AIDS has shown that we have only begun to scratch the surface in terms of the pandemic with its many faces and forms. Emotionally, physically, psychologically and spiritually, people have different dimensions. Various challenges have manifested itself in this regard and I am only now beginning to understand migrant workers; their displacement, their challenges away from home and the impact of HIV upon their lives. This was made possible through this postfoundationalist approach. Focusing on migrant workers, a whole new world opened for me as I listened to their stories where they could express themselves in a safe environment.

This approach remains open for critical evaluation and correction. I am aware that I have not adequately addressed the concerns of migrant workers affected by HIV and/ or AIDS, but this was not my intention. However, their experiences of God allowed me a glimpse of God's activity in this world of ours. I have also focussed on the practical, the day to day issues like employment, housing and health care. Broad strokes were taken which could have been improved with more reflection from my co-researchers. What I have learned from this is that I should stay closer to my coresearchers and not just write about them, but with them. Constant reflection on their level is important, because they are the experts of their stories.

The participation of the church and God's activity could be perceived as skewed and for this I offer an apology. I do realise that I should have been more descriptive and that I could have offered more suggestions, without been prescriptive. Therefore, I consider this research as the beginning of a journey.

\section{References}

Braaten, C., \& Clayton, P., 1988, The theology of Wolfhart Pannenberg. Twelve American critiques, with an autobiographical essay and response, Augsburg Publishing House, Minneapolis.

Barbie, E.M. \& Mouton, J., 2001, The practice of social research, Oxford University Press, Cape Town.

Denzin, N.K. \& Lincoln, Y.S. (eds.), 2008, Introduction the discipline and practice of qualitative research, Collecting and interpreting qualitative materials, Sage Publications, California.

Gergen, K.J., An invitation to social construction, 2nd edn., Sage Publications, Cornwall. Hart, C., 1998, Doing a literature review. Releasing the social science imagination, Sage Publications, London.

Hančil, T., 1999, 'Evolution culture and theology', viewed 10 October 2009, from http://www.etf.cuni.cz/ hancil/texty/final.pdf

Müller, J.C., 2005, 'A Post Foundationalists, HIV Practical Theology', South African Journal of Practical Theology 20(2).

Müller, J.C., 2009, 'Transversal Rationality as a practical way to do interdisciplinary work with HIV and AIDS as a case study', paper delivered at the seventh international conference on new directions in the humanities, Beijing, China, 02-05 June.

Murphy, P. \& Perry, C., (eds.), 1989, The hidden grievers in Aids Principles, Practices \& Politics, Corless I.B. \& Pittman Lindeman M. Hemisphere Publishing Corporation, New York.

Rosenblatt, P.C., 2001, 'Qualitative research as a spiritual experience', in K.R. Gilbert (ed.), Emotional nature of qualitative research, n.p., CRC Press, London.

Van Dyk, A., 2001, HIV/ AIDS Care and Counseling. A multi disciplinary approach Pearson Education, Cape Town.

Van Huyssteen, W., 1997, Essays in postfoundationalist theology, Wm. B. Eerdmans Publishing Company, Michigan.

Van Huyssteen, W., 1998, Duet or duel? Theology and science in a postmodern world, SCM Press, London. 